\title{
Animal Representation in the Dutch Media through Environmental Ethics
}

\author{
Helen Kopnina
}

Received: 23 April 2014 / Accepted: 18 June 2014 / Published online: 28 June 2014

(C) Springer International Publishing Switzerland 2014

\begin{abstract}
This article examines two areas of tension within environmental ethics literature and relates them to the case study of the animal representation in the Dutch media. On the one hand, there is a tension between those who propagate clear division between anthropocentric and non-anthropocentric views; on the other hand, there is a tension between the land ethics perspective and animal right proponents. This article examines the media representation of animals using content analysis, and links the findings back to the areas of tension within environmental ethics. The main findings indicate that the division between anthropocentric and ecocentric perspectives is still relevant for evaluating the human-animal relations, while the convergence of the land ethics and animal rights perspectives can be helpful in explaining why this division is relevant.
\end{abstract}

Keywords Animals - Animal rights · Anthropocentrism - Case study · Content analysis · Dutch media $\cdot$ Ecocentrism $\cdot$ Environmental ethics

\section{Introduction}

One of the main focal points of environmental ethics is what is to be assigned an intrinsic value and, in prolongation, moral rights (Vincent 1992; Fox 1995). Naess $(1973,1989)$ has coined the terms deep and shallow ecology to express the distinction between more eco- or bio-centric and anthropocentric view of human relationship with nature. Deep ecologists argue that all life forms should be allowed to flourish and that all individual living organisms, species and ecosystems possess the intrinsic value. By contrast, shallow ecologists focus on environmental problems and welfare of animals only when they are connected to the well-being of people (Naess 1973). Environmental ethics and animal rights literature also identifies a number of tension areas. On the one hand, there is a tension between those who propagate clear division between anthropocentric and non-anthropocentric views; on the other hand, there is a tension between the land ethics perspective and animal right proponents.

These tensions and gradations in views are present in all societies, internalized through cultural norms, and transmitted through the public media. However, environmental ethics is not commonly

H. Kopnina $(\bowtie)$

The Hague University of Applied Science, The Hague, Netherlands

e-mail: alenka1973@yahoo.com 
discussed in the case of representation of animals in the public media (Pivetti 2005). This article explores these tensions and gradations between different views of the human-environment relationships. The following sections link deep and shallow ecology approaches to the representation of animals in the Dutch media using content analysis of the newspapers. Content analysis of newspapers provides an empirical basis for monitoring (shifts in) public opinion (Weber 1990; Stemler 2001) and can be particularly useful in relation to exploration of public attitudes to animals (Pivetti 2005; Packwood Freeman and Jarvi 2013). Public media approach has been chosen since the investigation of the social representations of animals explores the way individuals think about the long-standing issues, such as human relationship with animals (Wagner 1995). In the final section, this article reflects upon the relationship between animal representation and environmental ethics as well as animal welfare literature.

\section{Deep and Shallow Ecology}

Leopold's (1949) 'land ethic' assigns moral rights to species and to their habitats or the socalled entire biotic communities. Singer (1977) advocated the intrinsic value to all sentient creatures and implied that human beings must avoid needless suffering to all species able to feel pain. More restrictively, Regan (1983) advocated for the recognition of the intrinsic value ("what is desired for its own sake," and "what would be good even if it existed in isolation from everything else") of all mammals due to their supposed mental capacities. In this view, if animal life had been placed on an existential par with human life then non-humans' exploitation and that of their homelands would be morally unfeasible (Crist 2013).

By contrast, according to the shallow ecology thinkers, in instances involving human and animal encounters, animal death is rarely seen as anything other than the result of cultural practice as in the case of whaling communities (e.g., Kalland 2009), or collateral damage as in the case of animals killed by cars (e.g., Desmond 2013), or economic interest as in the case of kangaroo parts trade (e.g., Thorne 1998), or basic necessity as in the case of consumption (e.g., Kopnina 2013b), or symbolic ritual as in the case of animal sacrifice (e.g., Lévi-Strauss 1968). These representations can be defined in both material and aesthetic terms (Mathews 1994). Neither representation represents animals as victims (Fudge 2006), rendering animals as no more than culturally, socially or economically significant objects (Crist 2013).

While shallow ecology perspective calls for better welfare of domesticated animals, either as pets or as food, deep ecology perspective calls into question the very basis of animal use or consumption. For example, circus audiences are delighted to watch animals perform tricks, which are considered anthropogenic, such as begging for food, sitting down, counting and so on (Schunk 2011). In all their historical complexity, animals are not just surrogates for theory, they are not here just 'good to think with' as Lévi-Strauss (1968) has formulated it. Aside from positioning humans within the natural and ecological system, deep ecology perspective condemns human superiority above all other species (Crist 2012). Shallow ecology proponents leave the basic structures of advanced industrial societies intact (Ophuls 1977) and fail to reconsider major political, economic and social systems that support current imbalance in human-animal relationships (Devall and Sessions 1985; Devall 1993).

There are also gradations between these views. On the one hand, there is a tension between those who propagate clear division between anthropocentric and non-anthropocentric views; on the other hand, there is a tension between the land ethics and animal right proponents. The so-called environmental pragmatists, such as environmental philosophers Norton (1988) and Weston $(1985,1992)$, used the substantive content of pragmatic philosophy to adjust anthropocentrism, arguing that it is practically useful in terms of motivation for environmental action 
and actual policy-making. On the other hand, political philosopher Eckersley (1992), environmental sociologist Crist (2012), and environmental ethics philosopher Rolston III (1985, 1997, 2015) have argued that anthropocentrism is not sufficient in defending instrumentally 'useless' (in the anthropocentric utilitarian sense) species.

In regard to the second area of tension, the complex relationship between animal rights and environmental ethics is exemplified by Callicott's (1980) essay 'Animal Rights: A Triangular Affair'. In contrasting the ethical foundations of the "animal liberation" movement (e.g., Liddick 2006) with those of the "land ethic," Callicott (1980) reflects that while individual sentient animals are morally considerable by animal rights advocates, land ethic espouses a broader issue of integrity and stability of habitats and ecosystems as well as organisms belonging to these habitats as a starting point (Callicott 1980:131). Callicott's essay has caused criticism since it was seen to lead to the division between individualistic animal welfare ethics and holistic ecocentric ethics (e.g., Warren 1983).

In his consequent publication, Callicott (1989) responded that animal rights movement and the land ethics can be united under a common ethical umbrella despite occasional conflicts. This reconciliation is necessary, as Callicott (1989) himself admitted, as it would be far wiser to make common cause against a common critics that disregard the plight of non-humans, be they individual animals, plants, or habitats. Crist (2012) asserts that both ecocentric values and animal rights can be reconciled in their explicit critique of human tacit as well as manifest superiority over other species. In fact, anthropocentric and ecocentric concerns may overlap and complement each other (Gough et al. 2000), for example when people care of consumers about biological meat (which they find 'healthy for humans' and 'good for animals'). Multispecies ethnographies (ME) and Actor Network Theory (ANT) have the potential to bridge the gap between environmental ethics and animal rights.

Anthropocentrism is often attributed to the loss of spirituality and the shift toward economic capitalist priorities in advanced industrial societies (e.g., Alario and Freudenburg 2003; Taylor and Zimmerman 2005). Some authors have argued that faith in human superiority and progress has roots in the Judeo-Christian tradition (e.g., White 1967) and the Enlightenment with its pronounced human-centered worldview (e.g., Meyer 2001).

Ethnographic studies challenge the "noble savage" depiction of indigenous communities that were supposed to have lived in harmony with nature (Wagley 1976:302). Shepard (1993) and Richards (2014) have argued that pre-modern societies drew a distinct line between culture and nature or humans and animals at an early point in human history. Presently, this line has been more pronounced as the global forces of neoliberal capitalism and consumerism has affected all communities. Most globalized communities seemed to have internalized the ideology that prioritizes human, social and economic interests at the expense of others (Shoreman-Ouimet and Kopnina 2011; Kopnina 2012; Strang 2013).

\section{Actor Network Theory}

Actor Network Theory (ANT) postulates that the relationships between people and animals are intimately interdependent and there is no a priori distinction to be made between humans and non-humans, and that these distinctions are subject to change and negotiation (e.g., Callon 1986; Law 1986; Latour 1988; Whatmore and Thorne 1998) as well as co-constitutive relationships between people and animals (Healy 2007).

ANT led to exploration of emotional connection with nature (e.g., Milton 2002) and continuing the "more-than-human," "posthuman," and "relational" work in human geography (e.g., Whatmore 2002). ANT framework often evokes the social construction of humans and 
animals, leading researchers to explore how animals leave imprints on particular landscapes (Emel et al. 2002).

However, some scholars have noted that ANT's preoccupation with social and cultural constructionism obscures inherent imbalance of power between human and animal 'actors', rendering constructions intellectually and politically objectionable as they only serve humans that construct them. Constructions, both as a refutation and construction-as-philosophicalcritique (Demeritt 2002) have both political implications in implying that nature is a contingent phenomenon.

Alternative ways of relating to nature, both as a subjective entity and an objective reality, were proposed, exemplified by the work in multispecies ethnographies (ME). ME has emerged in part as a reflection of the ANT, in part as a combination of animal and environmental studies as well as science and technology studies (Kirksey and Helmreich 2010). In her work on human-animal relationships, Haraway $(2003,2007)$ announced the "species turn" in her own discipline of anthropology. Another anthropologist, Desmond (2013) applied the "species turn" to the phenomenon of the roadkill in North America, and the numerous rhetorical strategies in public discourse that are mobilized to render invisible this animal carnage. Expanding Michael's (2004) notion of intersecting human and animal mobility and other academic work associated with road safety and ecology, Desmond (2013) suggests reconsideration of the status of the animal from that of necessary collateral damage to that of a sentient being in need of human assistance. It is this kind of engaged framework that this article aims to apply to the case of representation of animals in the Dutch media.

\section{Case Study: Content Analysis of Dutch Newspapers}

Five most popular newspapers (NRC, Het Parool, De Volkskrant, De Telegraaf, and Metro) were selected for the content analysis. First four newspapers are subscription only and Metro is a free newspaper. The newspapers were analyzed on the basis of topics involving animals or human-animal relationships reflected both in the title and content of the articles. The articles were searched using the keywords involving the general term 'animal' (including birds, fish, insects, etc.), as well as individual species' (including varieties of pets, farm animals, and wild animals). Words (such as 'animal' or 'bird') and combinations of words (such as 'animal police' or 'bird watch') were used to determine the frequency of their appearance in articles.

The main topics were identified, clustered into the topic categories listed in Table 1 in the alphabetical order of topic abbreviations. Categories were defined as a group of words with similar meaning or connotations. Explanations of each topic are provided below.

Animal ambulance (Dierenambulance) AA: was established in 1978 by a volunteer and grew into a large volunteer organization in the nineteen eighties, becoming Central Animal Rescue Foundation in 1980. The ambulance's staff is ranging from veterinaries to police and administrative workers, and works together with subsidizing agencies and animal welfare NGO's. The animal ambulance aims to provide first aid to injured and sick animals and transport them to the nearest veterinarian or clinic. The animal ambulance is a foundation (a non-profit organization) and dependent on its donors and sponsors.

Animal medical care (Dierenkliniek) AM: Clinics and veterinarians providing medical care to animals.

Animal defense (Dierenbescherming) AD: The Animal defense with nearly 200,000 followers including members, donors and volunteers, representing the interests of all animals.

Animal Ritualized slaughter (Kosher/Halal) RS: Ritual slaughtering is done in accordance to the religious requirement of either the Jewish or Muslim religious faith. A small political 
Table 1 Topics per newspaper

\begin{tabular}{|c|c|c|c|c|c|c|}
\hline & NRC & Het parool & De telegraaf & De volkskrant & Metro & Total \\
\hline AA & 1 & 28 & 53 & 6 & 19 & 107 \\
\hline $\mathrm{AD}$ & 12 & 24 & 62 & 39 & 18 & 155 \\
\hline $\mathrm{AM}$ & 0 & 28 & 8 & 4 & 2 & 42 \\
\hline RS & 32 & 47 & 36 & 88 & 12 & 215 \\
\hline AP & 9 & 0 & 34 & 19 & 10 & 72 \\
\hline $\mathrm{BM}$ & 3 & 3 & 3 & 17 & 2 & 28 \\
\hline $\mathrm{CW}$ & 0 & 0 & 0 & 0 & 0 & 0 \\
\hline $\mathrm{PH}$ & 0 & 0 & 0 & 0 & 0 & 0 \\
\hline $\mathrm{PO}$ & 0 & 0 & 0 & 0 & 0 & 0 \\
\hline RK & 0 & 0 & 0 & 0 & 0 & 0 \\
\hline AW & 26 & 31 & 44 & 76 & 11 & 188 \\
\hline
\end{tabular}

party (two seats out of over one hundred total seats in government in 2011) called the Party for the Animals or PvdD (Partij voor de Dieren) proposed a ban on ritual slaughtering of animals for consumption, which was backed by a majority of the parties who are favoring a ban on the ritual slaughtering (the backing as of June 2012 has vanished).

Animal police (Dierenpolice) AP: A recently established institution (also known as animal cops), which is a special department of the Dutch police to fight animal abuse, to render assistance and try to prevent animal sufferings.

Animal Welfare AW: General topics associated with the physical and psychological wellbeing of animals as well as human concern for animal welfare.

Biological meat BM: Biological meat (sometimes designated as organic meat) animals are animals fed and kept in an animal friendly manner for meat production purposes.

Controlling wild populations CW: Means and regulations to control wild life (deer, Canada geese, horses, etc.) population.

Public hygiene and animals (rats, doves) PH: All matters related to public hygiene and animals.

Pets and their owners PO Topics related to pets and their owners. This category sometimes overlapped with AA, AD, AM, and AW.

Road kill RK: Animals that have been struck and killed by cars. The topic frequency is summarized in Table 1 below. Figure 1 identifies topics per newspaper.

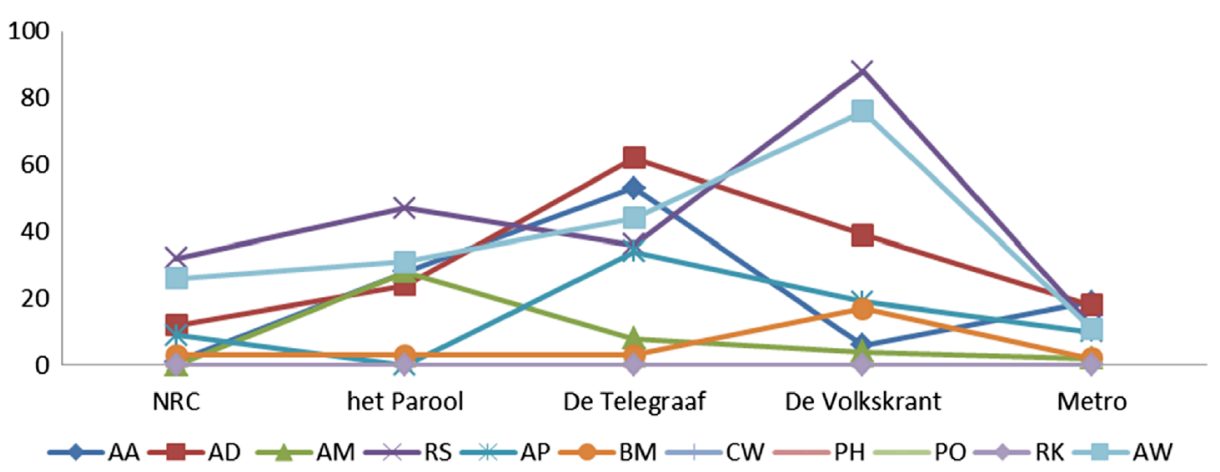

Fig. 1 Topics per newspaper 


\section{Discussion}

We shall now discuss each of the items in turn, starting with the most popular topics.

During the selected period the media attention to animals was dominated by ritual slaughter (RS, 215 articles) in accordance to the Jewish (Kosher) or Islamic (Halal) tradition. The major difference from the general practices in ritual slaughter is that the animals are not offered anesthetic prior to slaughter. The banning of such slaughter is viewed as a hostile act by a number of religious and ethnic groups (for detailed discussion see http://www. partyfortheanimals.nl/). The many articles commented on PvdD's party's 'marginal priorities' at the time when 'serious' issues, such as political instability, economic uncertainty, questions associated with employment, energy, and migration policy discussed by 'real' politicians.

Animal Welfare (AW, 188 articles) was the second-largest topic, dominated by articles on pets (110), farm animals (52), zoo animals (10) and 'other' (16). Curiously, AW did not overlap with the previous category and did not discuss welfare in the context of ritual slaughter.

Similar distribution is seen in the case of the third largest category, Animal Defense (AD, 155 articles): the pets (95), farm animals (31), zoo animals (3), and 'other' (26). Items related to $\mathrm{AD}$ were often intertwined with political discussion about the PvdA. PvdD was mentioned in 51 articles on $\mathrm{AD}$; and sometimes GroenLinks or GL party (Green Left) - this party was mentioned in 32 articles on AD. The site of Dierenbescherming keeps accurate track of the press articles.

Animal ambulance (AA, 107 articles) provides first aid and transportation to sick and injured pets, strays and wild animals (such as swans, hedgehogs and foxes) after reports of individuals or on behalf of police and firefighters. The organization provides an annual average of 14,000 services (average 40 per day) times to help animals. While the organization reports helping approximately $70 \%$ of all animals without owner: animals from the wild and stray animals, this help can only be offered with the donations from individuals and businesses and a contribution from the municipality (http://www.dierenambulance-amsterdam.nl/). The newspaper articles in the sample discussed the fact that many customer calls remained unanswered and that it is not really clear which wild (non-paying) animals are really helped.

Animal Police or 'animal cops' (AP, 72 articles) refers to the newly established (2010) institution, initialized by one of the members of Partij Voor Vrijheid or PVV (The Party for Freedom). In December 2, 2011 by the Security and Justice Minister established a new department 'the animal cops' within the Dutch Police Corps. In 2011, this institution involved police force with full law-enforcement powers, with the key responsibility is to fight and act against animal abuse, to render assistance and try to prevent animal sufferings. This idea created a wave of positive and negative news throughout the Netherlands. The discussion was often associated with humorous or derogatory term 'caviapolitie' (guinea pig police) since it is only concerned with pets, not farm or wild animals. As in the case of AD, AP was often mentioned in connection to political parties such as PVV, PvdA and GL. In De Telegraaf of 18 November 2011, it was noted that there are 55 animal cops trained in Amsterdam, whereas there is only work for 4 of them, thus making 'animal cops' redundant.

Animal medical care (AM, 42 articles) only contained five items mentioning rescue of wild animals, the rest of the items was linked to either farm animals or pets, or to general discussion of AM.

Biological meat, including free-range, organic, eco-conscious, etc. terms (BM, 28 articles) was mostly discussed in connection with AW but in particular context of human health. The category Public hygiene and animals, PH was not explicitly mentioned, but terms like 'animal 
welfare', 'sick farm animals', 'use of growth hormones', 'use of antibiotics', 'close quarters', 'no opportunity to be outside', 'battery chicken' were used under BM in combination with 'human health'.

One of the most significant trends in this analysis is that most of the discussion in the articles centers on pets and farm animals. Proportionally little discussion of wild or undomesticated animal species is included. The conspicuous absence of controlling wild population (CW) articles from the Dutch newspapers stands in contrast to cases reported by the political organizations and environmental non-governmental organizations (ENGO's) such as Party for the Animals; Milieudefensie or Dutch Friends of the Earth (http://www.milieudefensie.nl/english), Faunabescherming or Fauna Protection (http://www.faunabescherming.nl/) and the Dutch branch of World Wide Fund for Nature (http://www.wnf.nl/).

In regard to the shooting of 100,000 to 200,000 wild grey geese in 2011, Faunabescherming reported that many government controlled organizations such as 'Bird watch', 'Agrarian', and 'Nature and recreation' agencies, as well some NGO's allowed the slaughter due to factors ranging from 'protection of agricultural crops' to 'controlling unwanted population' to 'safety' when the geese were located close to the airports. The same organization has reflected that such action was necessitated by the lack of designated areas where geese can stay without imposing upon urban or agricultural areas (Faunabescherming 2011). It is important to note that the Dutch land division consists of 3,4 million land mass with 0,5 million hectare 'nature' (most of which is used recreationally as parks). Nature areas are receding under the influence of population growth and expansion of agricultural and urban areas of pavement and buildings take up more and more space (http://www.probos.net/bosdigitaal/html/doc_hoeveelbos_txt.html).

Another incident involved shooting of deer in South Holland area in the winter and spring of 2011 reported in publications of various ENGO, local or regional newspapers, or blogger sites (e.g., Leeman 2011). These incidences of wild animals that needed to be 'controlled' or 'managed' were not mentioned in either AW and AD items or elsewhere in the sample.

Recent newspaper articles have revealed the scale of industrial-scale production of animals for consumption, focusing on the so-called 'wild' animals traditionally used for Christmas meals, including turkey, pheasant, deer, hare and swine (Spits 2013). It was noted that most of these animals are now raised in close confinement and forced-fed, like the chickens and more 'traditional' farm animals that never see the light of day.

The commercial success of the documentary film De Nieuwe Wildernis (2013), translated as The New Wilderness, set in the Oostvaardersplassen, a nature reserve of high standard in the Netherlands, developed 40 years ago. The film includes the footage during all four seasons in the Oostvaardersplassen over a period of 2 years, featuring Konik horses, the red deer and foxes and Heck cattle, battling for survival on a small piece of land. The film has unleashed a media discussion about the value of wild nature in the Netherlands. Most discussions centered around the question whether starving animals should be shot or allowed to die 'naturally' (e.g., De Telegraaf 2014). The readers' poll in the Dutch newspaper De Telegraaf has revealed that the majority of over two thousand readers polled think that the common starling (the bird) should not be protected (De Telegraaf 2014). Quoted readers have expressed opinions ranging from 'All species can die out. Let nature take its course', and 'It's ridiculous that large building projects have to be stopped because of some small animals'.

\section{What is NOT Mentioned?}

While this article is limited to the study of the selected media, it is worth noting that what is NOT reported could make for an interesting follow-up research. Such an omission is the 
mention of the roadkill (RK), which is remarkable due to the fact that given the Dutch land mass the roads occupy a proportionally large territory. In The Netherlands car density in 2013 was 480 per 1,000 inhabitants (including those who cannot drive due to age or disability), up from 371 per 1,000 in 1991 (Eurostat 2014).

What is also not mentioned is the scale of daily consumption of animals, other than the discussion about the ritual slaughter. For example, in the case of chickens, according to CBS (2014) and waardelozehaantjes.nl/campagne, there are about 1,500,000 chickens for consumption, and 45,000 of other chickens (those that lay eggs but unsuitable for consumption) slaughtered every day.

\section{Reflection}

Due to the fact that most of the discussion in the Dutch newspapers centers around animal significance for cultural tradition and politics (e.g., ritual slaughter, animal police, $\mathrm{PvdD}$ ) or to animals as source of food (e.g., farm animals, biological meat, etc.) or other social functions (e.g., animal welfare directed at pets, etc.), the image of animals that emerges through this content analysis is dominated by instrumental (anthropocentric) themes. This is probably due to the obvious fact that there are many more farm animals and pets (and agricultural and urban spaces) than there are wild species (and natural habitats) in The Netherlands. On the other hand, examining the media coverage of such institutions and organizations as animal defense, animal ambulance and animal clinic, it also appears that concern for animals, particularly domestic ones is prevalent in the Dutch society. Recalling Gough et al. (2000) position, we note that anthropocentric and ecocentric concerns may be seen as overlapping as media reflects both concern for animals on which people are dependent (for food or entertainment) and concern for the animals themselves.

Reflecting on the most popular topic discussed in the sample, the ritual slaughter of the animals is prominent in current political agendas. The Party for the Animals' (PvdD) stance captured by the media underlies this ethic. PvdD manifesto states:

"After two centuries of animal protection it is high time that far-reaching restrictions are imposed on the use of animals. All too frequently animals are still regarded as objects, which are always subordinate to human interests and may also be used for all those interests. Even if it takes place in a sustainable fashion, the exploitation of animals and their biotope has unavoidably negative consequences for the animals and almost always ends with their demise. Each kind of interaction with and use of animals should, therefore, be continually subject to a careful weighing-up of the gravity of human interests and the consequences for the animal. The moral justification for compromising their welfare decreases as human interests become less imperative and the consequences for the animal more damaging.... With this approach, the use of animals for nonessential human interests can be reduced and precluded altogether. It is evident that this applies to the production of fur, circuses, bull-fighting, angling and other animalunfriendly forms of entertainment that involve animals". (http://www. partyfortheanimals.info/content/view/303).

Treatment of PvdD's opponents through the media resembles Regan's (1983) more selective stance that does not assign intrinsic value to all beings due to their mental capacities. In some of his writings, he assigns such value to all those who are subjects-of-a-life, whilst he adopts a more inclusive account elsewhere.

Topics associated with Animal Welfare and animal medical care (clinic, ambulance, etc.), considering the fact that the media articles indicate that these are mostly concerned with 
domestic or farm animals, can be seen as ecocentric concerns (since the animal welfare concern extends beyond humans) and the position of shallow ecology (since pets and farm animals are used by humans). Yet, protection of the 'urban pests' such as pigeons, rats, or 'weeds' (Kopnina 2013a), or other instrumentally 'useless' or 'left over' species cannot be guaranteed through anthropocentric values (Eckersley 1992).

Returning to the two areas of tension within environmental ethics literature mentioned at the beginning of this article, the division between anthropocentric and non-anthropocentric views may still be relevant for the analysis of the media representation of animals. On the other hand, the convergence of two variations of an ecocentric perspective, the land ethics and animal rights perspectives, can instruct us how both the 'land' - the country, the territory, and the ecosystem and the land's inhabitants, human and non-human, are conceived in the public media.

Returning to the film the New Wilderness, it is remarkable that the idea of 'nature taking its course' is used as a common justification for the human-induced habitat destruction. Clearly, survival and starvation of animals on small pieces of land are relegated to the domain of neoDarwinian evolution. 'Nature taking its course' implies that the dominant species, humans, 'natural right' to displace other species is seen as normative. It would be politically incorrect to propose the same solution for the survival and welfare of the human beings. Regulating mechanisms applied to the few remaining 'wild' Dutch residents, including sterilization and extermination stand in stark contrast to the increasingly anthropocentric priorities of the political leaders concerned about somewhat decreased consumption in the Netherlands (Kopnina 2014a). The question of the Dutch population and the scarcity of land is simply not discussed, other than by rightist political parties in relation to migration. Compromising any of the productive land for expanding wild areas is simply not seen as a political option (Kopnina 2014b).

More significantly, there is no public discussion about the value of animal life and welfare in relation to the taken for granted human rights and morally normative media disapproval of all forms of social and economic discrimination. This media analysis basically shows that, to rephrase George Orwell, some animals are obviously more equal than others. If we were to perceive The Netherlands as the case of the 'model' for the 'developing' world - highly populated, relatively efficient in production, with all or most productive land used for either agriculture or urban settlement, we can imagine that such a model will be detrimental for nonhuman species, if deep ecology is to be taken into consideration.

\section{Conclusion}

While the section above provided a very cursory presentation of themes condensed through content analysis, these themes are indicative of the types of social, political, and cultural debates that surround animal representation in a West European country, and present a scope for potential further analysis. When these topics are seen through the framework of environmental ethics, broader issues in regard to the role animals in today's post-industrial society emerge.

Actor Network Theory (ANT) and Multispecies ethnographies (ME) could help in outlining the struggles between humans and animals to create their "places" and livelihoods. Yet, while ANT and ME reveal co-constitutive relationships between people and animals, they do not necessarily address the power imbalances and fail to notice the overtly anthropocentric nature of human and animal interaction. ANT and ME, with their focus on social construction and metaphors of place, do not go far enough in exposing subordinate nature of human-nature relationship. 
From the newspaper analysis it appears that there is a lack of popular moral engagement with mass consumption of animals, political marginalization of the Party for the Animals, instances of slaughter of 'urban pests' such as pigeons. ANT and ME are also well-equipped to address the numerous rhetorical strategies in public discourse that are mobilized to render animals morally invisible. Yet, the employment of deep ecology and animal rights may be more potent in addressing some of the topics represented in the case study of Dutch media representation of animals. Consequent research of media representation of animals could lead to deeper insights about publicly expressed (environmental) ethics. These insights could instruct researchers as to how the media both reflects and possibly manipulates public opinion and attitudes towards animals, as well as articulates underlying values.

\section{References}

Alario M, Freudenburg W (2003) The paradoxes of modernity: scientific advances, environmental problems, and risks to the social fabric. Sociol Forum 18:193-214

Callicott JB (1980) Animal liberation: a triangular affair. Environ Ethics 2(4):311-328

Callicott JB (1989) Animal liberation and environmental ethics: back together again. http://digitalcommons. calpoly.edu/cgi/viewcontent.cgi?article=1703\&context=bts

Callon M (1986) Some elements of a sociology of translation: domestication of the scallops and the fishermen of St. Brieuc Bay. In: Law J (ed) In Power, Action, Belief: A new sociology of knowledge. Routledge and Kegan Paul, London, pp 196-233

CBS (2014) Vleesproductie; aantal slachtingen en geslacht gewicht per diersoort. [Meatproduction; a number of slaughtered animals per weight] http://statline.cbs.nl/StatWeb/publication/?VW=T\&DM=SLnl\&PA= 7123SLAC\&LA=nl

Crist E (2012) Abundant Earth and population. In: Philip C, Eileen C (eds) In Life on the Brink: Environmentalists confront Overpopulation. University of Georgia Press, Athens, pp 141-153

Crist E (2013) Ecocide and the extinction of animal minds. In: Bekoff M (ed) Ignoring Nature No More: The Case for Compassionate Conservation. Chicago University Press, Chicago

De Nieuwe Wildernis: Grote Natuur in Het Klein Land [The New Wildness: Big Nature in a Small Country] (2013) Documentary Film. http://www.denieuwewildernis.nl/.

De Telegraaf (2014) Uitslag stelling: natuur haar gang laten gaan (Results of the poll of the day: let nature take its course) http://www.telegraaf.nl/watuzegt/22190417/_Nederland_moet_natuur_beter_beschermen_html. January 7.

Demeritt D (2002) What is the 'social construction of nature'? a typology and sympathetic critique. Prog Hum Geogr 26(6):767-790

Desmond J (2013) Requiem for roadkill: death and denial on America's roads security. In: Kopnina H, Shoreman-Ouimet E (eds) In Environmental Anthropology: Future Directions. Routledge, New York

Devall B (1993) Living richly in an age of limits: using deep ecology for an abundant life. Gibbs Smith Publishers, Salt LakeCity

Devall B, Sessions G (1985) Deep ecology: living as if nature mattered. Peregrine Smith Books, Salt Lake City

Eckersley R (1992) Environmentalism and political theory: towards an ecocentric approach. UCL Press, New York

Emel J, Wilbert C, Wolch J (2002) Animal geographies. Soc Anim 10(4):1-6

Eurostat (2014) 'Motorization rate cars per 1,000 inhabitants'

Faunabescherming (2011) Natuurorganisaties voor het schieten van 100,000 ganzen. (Environmental organization for shooting 100,000 geese). http://www.faunabescherming.nl/2011/05/04/natuurorganisaties-voor-hetschieten-van-100,000-ganzen/

Fox W (1995) Toward a transpersonal ecology. Developing new foundations for environmentalism. State University of New York Press, New York

Fudge E (2006) Brutal reasoning: animals, rationality, and humanity in early modern England. Cornell University Press, Ithaca

Gough S, Scott W, Stables A (2000) Beyond O'Riordan: balancing anthropocentrism and ecocentrism. Int Res Geogr Environ Educ 9(1):36-47

Haraway D (2003) Companion species: dogs, people, and significant otherness. Prickly Paradigm Press, Chicago

Haraway D (2007) When species meet (Posthumanities). University of Minnesota Press, Minneapolis

Healy S (2007) Deadly dingoes: 'wild' or simply requiring 'due process'? Soc Stud Sci 37(3):443-471 
Kalland A (2009) Unveiling the whale: discourses on whales and whaling. Studies in Environmental Anthropology and Ethnobiology Series. Berghahn Books, New York

Kirksey SE, Helmreich S (2010) The emergence of multispecies ethnography. Cult Anthropol 25(4):545-576

Kopnina H (2012) Towards conservational anthropology: addressing anthropocentric bias in anthropology. Dialect Anthropol 36(1):127-146

Kopnina H (2013a) Requiem for the weeds: reflections in Amsterdam city park. Sustain Cities Soc 9:10-14

Kopnina H (2013b) An exploratory case study of Dutch children's attitudes towards consumption: implications for environmental education. J Environ Educ 44(2):128-144

Kopnina H (2014a) Consumption, waste and (un) sustainable development: reflections on the Dutch holiday of Queen's Day. Environ Syst Decisions 34(2):312-322

Kopnina H (2014b) Christmas tale of (un) sustainability: reflecting on consumption and environmental awareness on the streets of Amsterdam'. Sustain Cities Soc 10:65-71

Latour B (1988) The pasteurization of France. Harvard University Press, Cambridge

Law J (1986) On the methods of long-distance control: vessels, navigation, and the Portuguese route to India. In: Law J (ed) In Power, action and belief: a new sociology of knowledge? Routledge and Kegan Paul, London, pp 234-263

Leeman R (2011) 'Damherten afschieten: de waanzin regeert' (Deer shooting: the insanity reigns) http://www. dichtbij.nl/zuid-kennemerland/lifestyle/zorg-en-welzijn/artikel/1955726/damherten-afschieten-de-waanzinregeert-.aspx

Leopold A (1949) A sand county almanac. Oxford University Press, Oxford

Lévi-Strauss C (1968) The savage mind, University Of Chicago Press

Liddick DR (2006) Eco-terrorism: radical environmental and animal liberation movements. Praeger Publishers, CT

Mathews F (1994) The ecological self. Routledge, London

Meyer JM (2001) Political nature. Environmentalism and the interpretation of Western thought. Massachusetts \& London, MIT Press, Cambridge

Michael M (2004) Roadkill: beween humans, nonhuman animals, and technologies. Soc Anim 12(4):277-298

Milton K (2002) Loving nature: toward an ecology of emotion. Routledge, New York

Naess A (1973) The shallow and the deep: long-range ecology movement. A summ Inq 16:95-99

Naess A (1989) Ecology, community and lifestyle: outline of an ecosophy. Cambridge University Press, Cambridge

Norton BG (1988) The constancy of Leopold's land ethic. Conserv Biol 2(1):93-102

Ophuls W (1977) Ecology and the politics of scarcity. Freeman, San Francisco

Packwood Freeman C, Jarvi JL (2013) The cultural politics of animals and the environment in the mass media. In: Bekoff M (ed) Ignoring Nature No More: The Case for Compassionate Conservation. Chicago University Press, Chicago

Pivetti M (2005) Natural and unnatural: animal welfare and rights activists' representations of animals and animal biotechnology in Italy. Department of Social Psychology, University of Helsinki. On-line: http:/www. animalliberationfront.com/Philosophy/naturala.pdf

Regan T (1983) The case for animal rights. University of California Press, Berkeley

Richards J (2014) The world hunt: an environmental history of the commodification of animals, University of California Press

Rolston HIII (1985) Duties to endangered species. Bioscience 35:718-726

Rolston H III (1997) Nature for real: is nature a social construct? In: Chappell TDJ (ed) The Philosophy of the Environment. University of Edinburgh Press, Edinburgh

Rolston H III (2015) Environmental ethics for tomorrow: sustaining the biosphere. In: Kopnina H, ShoremanOuimet E (eds) Sustainability: key issues. Routledge Earthscan, New York

Schunk H (2011) In what respects are animals 'good to think with'? An evalution of Claude Levi-Strauss animal comperative theory in totemism http:/goldsmiths.academia.edu/HenrikSchunk/Papers/103325/In_what_ respects_are_animals_good_to_think_with_An_evalution_of_Claude_Levi-Strauss_animal_comperative_ theory_in totemism

Shepard P (1993) On Animal Friends. In: Kellert SR, Wilson EO (eds) The biophilia hypothesis. Island Press, Washington, pp 275-300

Shoreman-Ouimet E, Kopnina H (2011) Introduction: environmental anthropology yesterday and today'. pp. 135. Environmental Anthropology Today. Routledge, New York

Singer P (1977) Animal liberation: a new ethics for our treatment of animals. Avon Books, New York

Spits (2013) Plofkalkoen en kooikonijn als fopwild (Factory-fed turkey and caged rabbit as 'wild' meat): http:// www.spitsnieuws.nl/archives/binnenland/2013/12/plofkalkoen-en-kooikonijn-als-fopwild

Stemler S (2001) An overview of content analysis. Practical Assessment, Research \& Evaluation, pp 7-17

Strang V (2013) Notes for plenary debate - ASA-IUAES conference, Manchester, 5-10 ${ }^{\mathrm{TH}}$ August 2013. Motion: 'Justice for people must come before justice for the environment'. http://www.youtube.com/watch? $\mathrm{v}=$ oldnYTYMx-k 
Taylor B, Zimmerman M (2005) The Encyclopedia of Religion and Nature. Continuum, London Thorne L (1998) Kangaroos: the non-issue. Soc Anim 6:167-182

Vincent A (1992) Modern Political Ideologies. Blackwell, Oxford

Wagley C (1976) [1953] Amazon town. Oxford University Press, New York

Wagner W (1995) Description, explanation and method in social representation research. Papers on Social Representations, 4. http://www.psr.jku.at/psrindex.htm

Warren MA (1983) The rights of the nonhuman world. In Robert Elliot and Arran Gare, Environmental philosophy: a collection of readings. The Pennsylvania State University Press, University Park, pp 109-131 Weber RP (1990) Basic content analysis, 2nd edn. Newbury Park, CA

Weston A (1985) Beyond intrinsic value: pragmatism in environmental ethics. Environ Ethics 7:321-339

Weston A (1992) Before environmental ethics. Environ Ethics 14:321-338

Whatmore S (2002) Hybrid geographies: natures cultures spaces. Sage, London

Whatmore S, Thorne LB (1998) Wild (er) ness: reconfiguring the geographies of wildlife. Trans Inst Br Geogr $23: 435-454$

White L (1967) The historical roots of our ecologic crises. Science 155(3767):1203-1207 